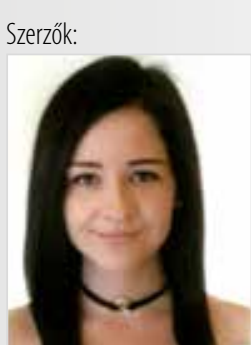

HOLLÓ BOGLÁRKA

IV. éves hallgató Érdeklődési kör: idősek mozgásterápiája, rehabilitáció rekefk@uni-miskolc.hu

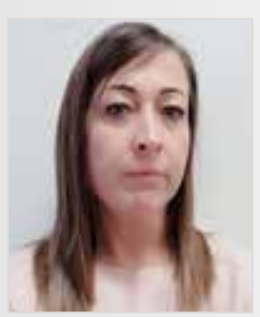

VÁMOSNÉ FAZEKAS ANITA mesteroktató rekefk@uni-miskolc.hu Érdeklő́dési kör: Rehabilitáció, fizioterápia és egészség megö́rzés/ fejlesztés minden korosztályban

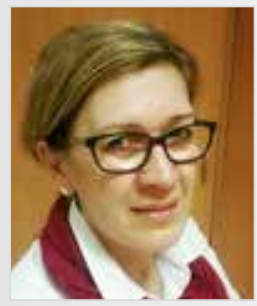

SZTOJEV - ANGELOV ILONA mesteroktató

Érdeklődési kör: ápolástudomány, egészségmagatartás, egészségkulturáltság, rehabilitáció rekefk@uni-miskolc.hu

\section{KOPPÁNYNÉ SZENDRÁK} MÁRIA

mesteroktató

Érdeklődési kör: fizioterápia és

masszázsterápia minden korosztály számára

rekefk@uni-miskolc.hu

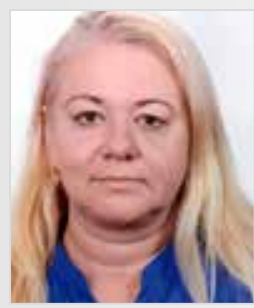

Szerző / rovatvezetô: DR. K. PLACHY JUDIT Munkahely: Miskolci Egyetem Egészségügyi Kar Fizioterápiás Intézeti Tanszék - adjunktus efkplachy@uni-miskolc.hu Érdeklődési kör: fizikai rekreációs foglalkozások tartása minden korosztály, leginkább a nyugdíjas lakosság számára.

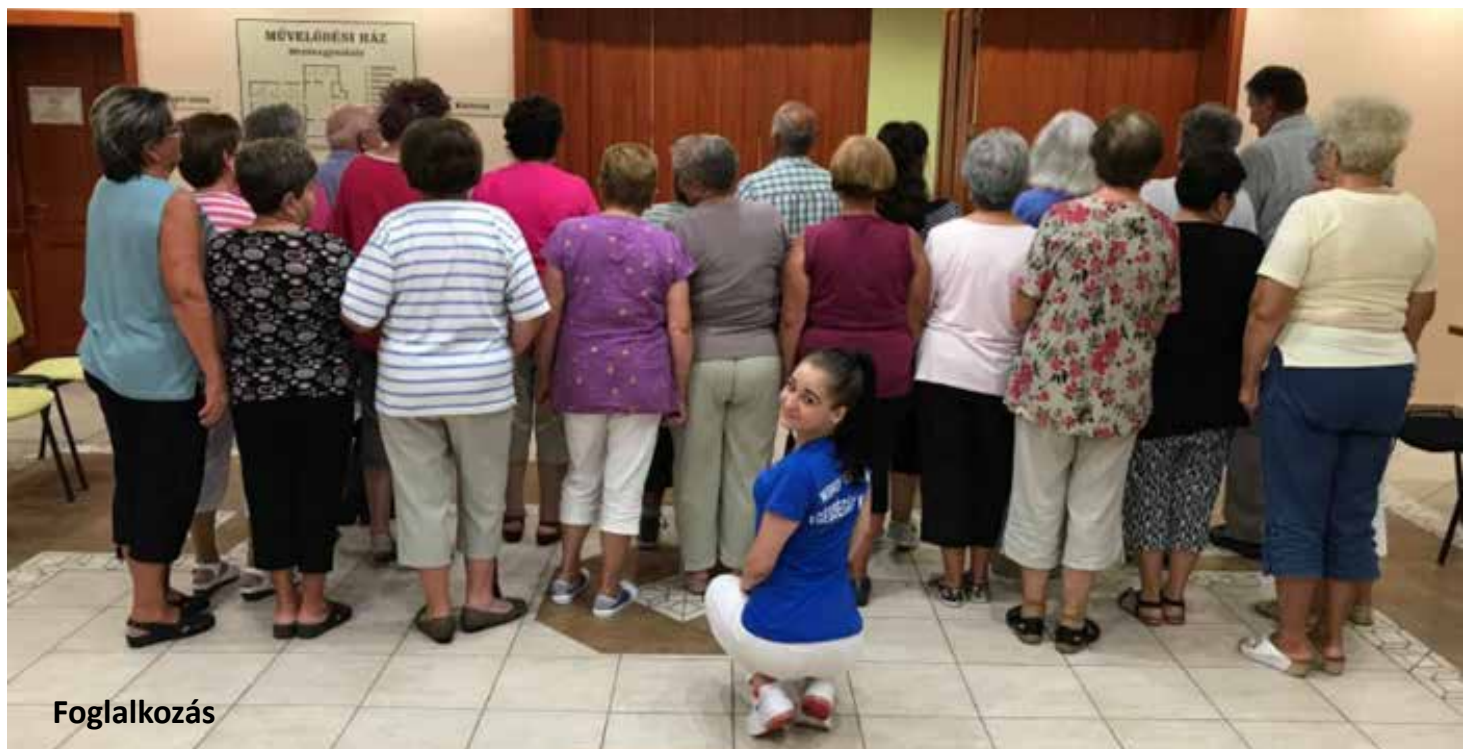

\title{
Az egyensúly és koordináció fejlesztése időskorban
}

ÖSSZEFOGLALÁS: Időskorban probléma a koordináció- és az egyensúlyzavar, melynek következtében megnő az ezekből adódó elesések, valamint a csonttörések száma. Az esések hátterében jelen vannak az izomerő-csökkenéses problémák, a megjelenő mozgásszervi elváltozások és az időskorban gyakori betegségek is. Jelen cikkben célunk az egyensúly és koordináció rövid távú fejlesztése, a rendszeresen végzett mozgásprogram hatásvizsgálata az esések prevenciója céljából. Mezőnagymihályon vizsgáltunk 60 év feletti, önellátásra képes nőket és férfiakat ( $\mathrm{N}=38$ fő;

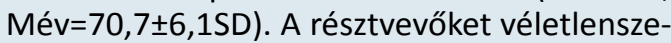
rűen két csoportba soroltuk. Kezelt csoport ( $N=19$ fö; Mév=70,3 $\pm 4,0 S D$ ), Kontrollcsoport

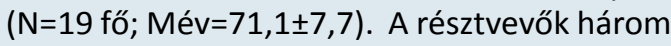

hónapon át heti három alkalom 45 perces csoporttornán vettek részt. Az elő- és utóméréseket fizioterápiás módszerekkel végeztük. Az adatfeldolgozás SPSS 24.0 számítógépes program segítségével készült. Néztünk átlagot, szórást és kétmintás t-próbát $(p<, 05)$. A kezelés hatására az idős mintában szignifikánsan javult az izomerő, az egyensúly, az állóképesség és a koordináció. Következtetésképp elmondható, hogy a vidéki időskorú lakosság egészségi állapota számos gondozási és kezelési feladatot igényel. Ezen probléma megoldásában gyógytornász - fizioterapeuta szakember jelenléte jelentős.

Kulcsszavak: fizioterápia, csoporttorna, motoros képességek, 60 év fölötti korosztály
ABSTRACT: Coordination and imbalance are frequent problems in old age. These results lead to increased number of falls and fractures. The most common reasons of falls are the decreased muscle strength, movement disorders and the evolving illnesses. Our aim was to examine the changes of balance and coordination by the short period training program. Women and men were examined in Mezőnagymihályi ( $N=38$; Myear=38; $70.7 \pm 6.1 S D)$. Participants were randomly divided into two groups. Training group ( $\mathrm{N}=19$; Myear $=0,3 \pm 4.0 S D$ ), Control group ( $N=19 ; \mathrm{My}$ ear=71.1 $\pm 7.7 \mathrm{SD}$ ). Training group did $45 \mathrm{~min}$ utes three months long training program three times per week. Pre- and post-measurement were examined by physiotherapy methods. Data were analysed with descriptive statististic and independent $t$-test with SPSS 24.0 statistic program $(p<.05)$. The muscle strength, the balance, the coordination and the stamina were significantly improved at the end of the training. By the conclusion the health of the elderly in the countryside requires many care and treatment tasks. The presence of the problem could be significantly solve by physiotherapists.

Key words: physiotherapy, group training, motor functions, elderlies over 60 years 


\section{Bevezetés}

Időskorban probléma a koordináció- és egyensúlyzavar, melynek következtében megnő az ezekből adódó elesések, valamint törések száma (Kovács, 2016).

$\mathrm{Az}$ esések hátterében jelen vannak az izomerő-csökkenéses problémák és a megjelenő mozgásszervi elváltozások, betegségek is (Síró, 1999). A 65 év felettiek legalább egyharmada minimum egyszer elesik évente. Az idősek traumákat szenvednek el, és kialakulhat a mozgástól való félem (Tóth, 2008).

Az időskori megbetegedésből kifolyóan akár a munkaképesség, az önellátás és az időskori függetlenség is sérülhet, ezt bizonyítja, hogy a munkaerőpiacon az inaktív 65 éven felüliek aránya 2005-ben 37,5\% volt, mely 2030-ra meghaladhatja az 54\%-ot (Semsei, 2010).

Gazdasági teher hárul az országra azért is, mert a vezető halálok az ápolási időben rövidebb és gazdaságilag kevesebb ráfordítást jelentő fertőző betegségektől eltolódott a krónikus betegségek irányába. Magyarországon elsősorban a szív- és érrendszeri megbetegedések felé, de magas számot mutatnak az önálló életvitelt korlátozó mozgatószervrendszeri elváltozások is (Semsei, 2010).

Ezen okokból kifolyólag jelen célunk az egyensúly és koordináció rövid távú fejlesztése, a rendszeresen végzett mozgásprogram hatásvizsgálata az esések prevenciója céljából.

\section{Módszerek}

A mintaválasztás és a kiválasztott módszerek korábbi szakirodalmak elemzése alapján történt.

\section{Minta}

A mintát a mezőnagymihályi lakosság tagjai alkották 2019. július és szeptember hónap között. Beválasztás kritériumai a következők voltak:

- Önkéntesség

- 60 év feletti életkor

- Önellátásra való képesség

- Egyéb terápiában nem részesülés

A résztvevőket véletlenszerűen két csoportba soroltuk (1. ábra).

\section{Mérés}

Az elő- és utóméréseket fizioterápiás módszerekkel végeztük.

A betegvizsgálat Mezőnagymihályi Orvosi Rendelő kezelőtermében történt:

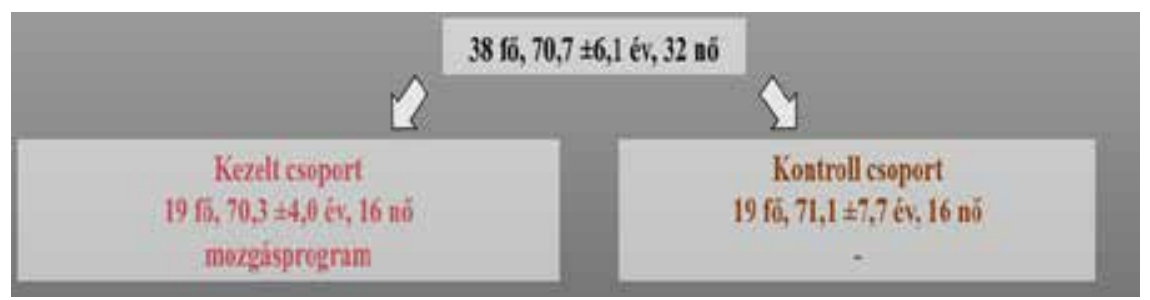

\section{1. ábra: A minta}

- Gerinc (2 sík) és végtagi ízületek megtekintéses vizsgálata,

- Abszolút végtaghossz és aktív mozgásterjedelem (gerinc, csípő, térd, boka) mérése,

- 6MWD,

- Statikus izomerő (4 izomcsoport), egyensúly (3 darab) és koordináció (3 darab) mérése funkcionális tesztekkel,

- Közvetett megkérdezéssel: társbetegségek, a segédeszköz-használat, korábbi csonttörések-elesések száma, aktivitás, fájdalom, egyensúlyt és koordinációt igénylő mindennapi tevékenységek.

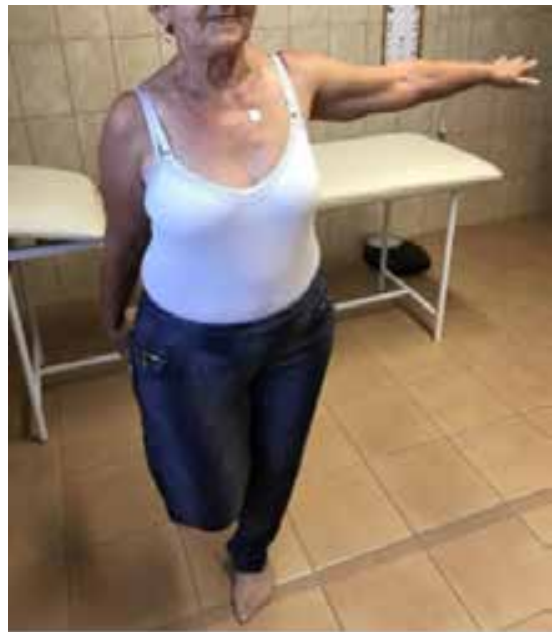

2. ábra: Mérés

\begin{tabular}{|c|c|c|c|}
\hline Funkcionális deficitek & $\begin{array}{l}\text { Résztvevők } \\
\text { (fő \%) }\end{array}$ & Átlagok & Kategóriák \\
\hline Gyengült izomerő & $38100 \%$ & $22,8 \mathrm{sec}$ & gyenge: $20-40$ sec \\
\hline Egyensúlyi probléma & $38100 \%$ & $6,0 \mathrm{sec}$ & elfogadható: 5-19 sec \\
\hline Mozgásterjedelem beszükülése & $38100 \%$ & - & - \\
\hline $\begin{array}{l}\text { Terápiát befolyásoló } \\
\text { társbetegségek megléte }\end{array}$ & $3592,1 \%$ & 1,9/fö & - \\
\hline Tartáshiba & $3386,8 \%$ & 1,8/fö & - \\
\hline Állóképesség csökkenése & $3284,2 \%$ & $242,1 \mathrm{~m}$ & $\begin{array}{l}\text { súlyos probléma: } \\
<249 \mathrm{~m}\end{array}$ \\
\hline $\begin{array}{c}\text { Koordinációs probléma két lépés elöre, } \\
\text { egy lépés hátra teszt estén }\end{array}$ & $2976,3 \%$ & $43,1 \mathrm{sec}$ & $\begin{array}{l}\text { elfogadható: } \\
40-50 \mathrm{sec}\end{array}$ \\
\hline $\begin{array}{l}\text { Koordinációs probléma } \\
\text { négy négyzet teszt esetén }\end{array}$ & $1847,4 \%$ & $23,2 \mathrm{sec}$ & $\begin{array}{l}\text { gyenge: } \\
>15 \mathrm{sec}\end{array}$ \\
\hline Ízületi deformitás, tengelyállási hibák & $1334,2 \%$ & 1,4/fö & - \\
\hline
\end{tabular}

2. táblázat: Eredmények a visszamérés után csoportonként

\begin{tabular}{|c|c|c|c|}
\hline & $\begin{array}{c}\text { Kezelt } \\
\text { csoport } \\
(\mathbf{n}=19)\end{array}$ & $\begin{array}{c}\text { Kontroll- } \\
\text { csoport } \\
(\mathbf{n}=19)\end{array}$ & Különbség \\
\hline Törzs extensor csoport (s) & 36,4 & 12,7 & $\mathrm{p}=0,019$ \\
\hline Musculus gluteus maximus (s) & 29,9 & 19,9 & $\mathrm{p}=0,046$ \\
\hline Musculus quadriceps femoris (s) & 50,0 & 26,1 & $\mathrm{p}=0,001$ \\
\hline Musculus triceps surae (s) & 31,8 & 17,6 & $\mathrm{p}=0,006$ \\
\hline Módosított gólya (s) & 12,1 & 4,4 & $\mathrm{p}=0,000$ \\
\hline Módosított flamingó (s) & 12,7 & 5,7 & $\mathrm{p}=0,000$ \\
\hline Csukott szemmel való egy lábon állás (s) & 6,2 & 3,5 & $\mathrm{p}=0,000$ \\
\hline Négy négyzet (s) & 9,9 & 15,8 & $\mathrm{p}=0,000$ \\
\hline Két lépés előre és egy lépés hátra (s) & 22,7 & 45,0 & $\mathrm{p}=0,000$ \\
\hline Módosított up and go (s) & 7,2 & 15,4 & $\mathrm{p}=0,000$ \\
\hline Állóképesség (m) & 345,9 & 249,6 & $\mathrm{p}=0,003$ \\
\hline
\end{tabular}


A kezelés módszere csoportos gyógytorna volt, 45 perc heti 3 alkalommal a Mezőnagymihályi Művelődési Ház rendezvénytermében zajlott 18:30 - 19:15 óra között (2. ábra).

Az adatfeldolgozás SPSS 24.0 számítógépes program segítségével történt. Néztünk átlagot, szórást és kétmintás t-próbát (p<,05).

\section{Eredmények}

Bemutatjuk a minta jellemzését az előmérés alapján (1. táblázat)

A csoportok között kiinduláskor szignifikáns eltérést egy koordinációs tesztben $(\mathrm{p}=0,056)$ találtunk, ezért a két csoportot homogénnek tekintjük. A kezelést követően azonban minden vizsgálati paraméterben szignifikánsan jobban teljesített a Kezelt csoport (2. táblázat).

A Kezelt csoport esetében összehasonlítottuk az elő- és utómérés eredményeit. Itt egyedül a „Törzs extenzor csoport” esetében nem találtunk szignifikáns változást (3. táblázat).

\section{Összegzés}

Az általunk összeállított vizsgálati módszertan alkalmas volt a minta jellemzésére. A 70 év fölötti férfiak és nők esetében minden résztvevőt érintett a beszükült mozgásterjedelem, a gyengült izomerő, az egyensúlyi probléma, és nagyon gyakori hiba volt a terápiát befolyásoló társbetegségek megléte, a tartáshiba, valamint a csökkent állóképesség.

Mint a korábbi eltérő városokban végzett kutatások is bizonyítják, a rendszeres fizikai aktivitás hatására javíthatók a motoros képességek idős korban is (Mácsár - Plachy, 2019; Vécseyné et al., 2013; Barthalos et al., 2012). A kezelés hatására a mi mintánkban is szignifikánsan javult az izomerő, az egyensúly, az állóképesség és a koordináció.

Bebizonyosodott, hogy a vidéki időskorú lakosság egészségi állapota számos gondozási és kezelési feladatot igényel. Ezen probléma megoldásában a gyógytornász - fizioterapeuta szakember jelenléte jelentős (ábra, $3,4)$.

\section{Irodalomjegyzék}

Barthalos, I. - Bognár, J. - Fügedi, B. - Kopkáné, P. J. - Ihász F. (2012): Physical performance, body composition, and quality of life in elderly women from clubs for the retired and living in twilight homes. Biomedical

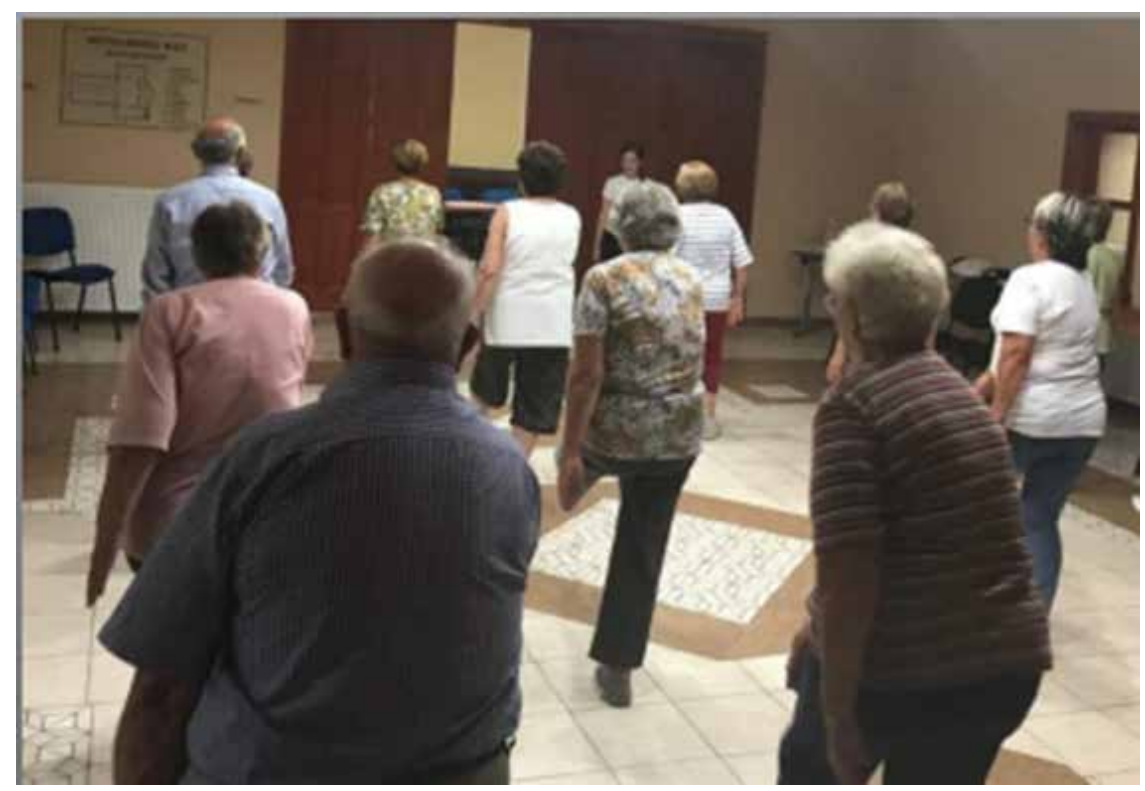

\section{3. ábra: Csoporttorna}

3. táblázat: Eredmények a visszamérés után a Kezelt csoportban

\begin{tabular}{|c|c|c|c|}
\hline & $\begin{array}{c}\text { Kezelés } \\
\text { elött }\end{array}$ & $\begin{array}{c}\text { Kezelés } \\
\text { után }\end{array}$ & Különbség \\
\hline Törzs extensor csoport (s) & 24,1 & 36,4 & $\mathrm{p}=0,058$ \\
\hline Musculus gluteus maximus (s) & 20,1 & 29,9 & $\mathrm{p}=0,006$ \\
\hline Musculus quadriceps femoris (s) & 31,1 & 50,0 & $\mathrm{p}=0,002$ \\
\hline Musculus triceps surae (s) & 15,0 & 31,8 & $\mathrm{p}=0,000$ \\
\hline Módosított gólya (s) & 6,5 & 12,1 & $\mathrm{p}=0,001$ \\
\hline Módosított flamingó (s) & 6,4 & 12,7 & $\mathrm{p}=0,000$ \\
\hline Csukott szemmel való egy lábon állás (s) & 5,0 & 6,2 & $\mathrm{p}=0,000$ \\
\hline Négy négyzet (s) & 17,9 & 9,9 & $\mathrm{p}=0,000$ \\
\hline Két lépés elöre és egy lépés hátra (s) & 31,7 & 22,7 & $\mathrm{p}=0,001$ \\
\hline Módosított up and go (s) & 10,4 & 7,2 & $\mathrm{p}=0,001$ \\
\hline Állóképesség (m) & 257,5 & 345,9 & $\mathrm{p}=0,000$ \\
\hline
\end{tabular}

Human Kinetics, 4. 45-48. o.

Kovács, É. (2016): Az időskori elesések megelőzése. Rehabilitáció. 26. 3. 134-138. o.

Mácsár, G. - K. Plachy, J. (2019): Hat hónapos intervenciós program hatása a fittségi állapotra és az életminőségre 60 év felett. Recreation. 4. 24-27. p.

Semsei, I. (2010): A gerontológia oktatása. Magyar Gerontológia, 5 . 4-15. p.

Siró, B. (1999): Speciális szempontok. Elesés idős korban. 64. o.

Tóth, M. (2008): Szédülés és elesések idős korban. 20. o.

Vécseyné, K. M. - Kopkáné, P. J. - Bognár, J. - Olvasztóné, B. Zs. Barthalos, I. (2013): Effects of Pilates and aqua fitness training on older adults' physical functioning and quality of life. Biomedical Human Kinetics, 5. 22-27.

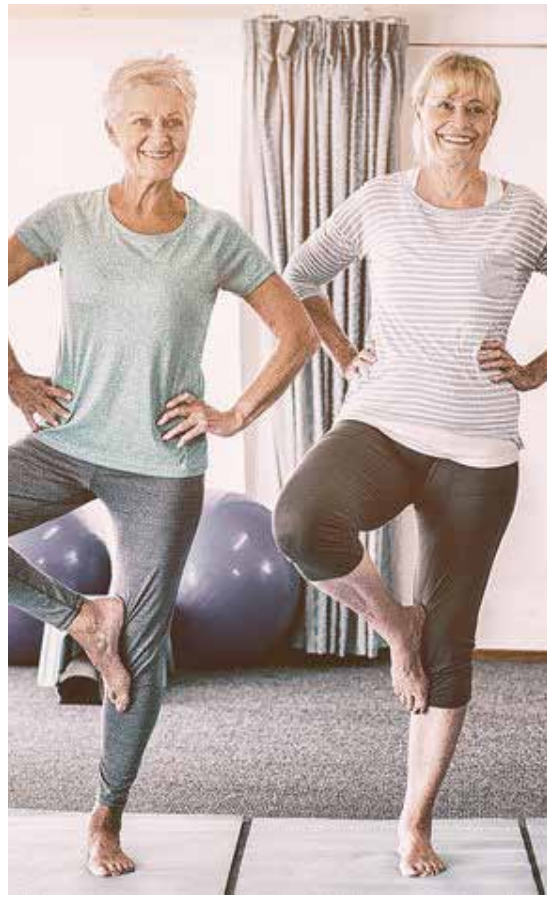

